\title{
DINAMIKA NASIONALISASI DE JAVASCHE BANK: SEBUAH PERJUANGAN MENJADI BANK INDONESIA (1950-1953)
}

\author{
Nurbaity, Arief Hidayat, Fahmi Hidayat \\ Email : nurbaity_muthalib@yahoo.com \\ Universitas Indraprasta PGRI Jakarta
}

\begin{abstract}
Abstrak
Sebagai bangsa yang telah merdeka dan diakui kedaulatannya pada tahun 1949, Indonesia menginginkan segala sendi kehidupan bangsa dipegang dan dikelola sendiri oleh bangsa Indonesia. Hal tersebut tak terkecuali di bidang perbankan. Perbankan Indonesia salah satunya dan terbesar adalah De Javasche Bank masih dikelola oleh bangsa asing yakni Belanda pada saat itu.Hal itu tentunya bertentangan dengan amanat UUD 1945, yang mengamanatkan untuk mencapai kesejahteraan rakyat Indonesia. Amanat UUD 1945 itu termaktub dalam pasal 33 yang digariskan dalam pemikiran ekonomi Indonesia sebagai Nasionalisme Ekonomi Indonesia. Berdasarkan amanat UUD 1945 pasal 33 dan sebagai perwujudan dari nasionalisme ekonomi Indonesia, maka pemerintah menjalankan perombakan perekonomian dari yang bercorak ekonomi kolonial menjadi ekonomi nasional melalui nasionalisasi segala milik asing di Indonesia. Salah satu milik asing yang dinasionalisasi oleh pemerintah Indonesia adalah De Javasche Bank. Javasche Bank adalah sebuah lembaga perbankan swasta yang didirikan pada tahun 1828. Sampai tahun 1850-an, Javasche Bank masih merupakan satu-satunya lembaga swasta yang memberikan kredit kepada pedagang yang terikat cultuurstelsel. Nasionalisasi tidak dilakukan dengan penyerobotan asset milik Belanda ini tetapi pemerintah Indonesia membeli saham De Javasche Bank dari pemiliknya. Nasionalisasi De Javasche Bank dilakukan dengan berbagai persiapan seperti pembentukan panitia dan menyusun alat kelengkapan seperti Undangundang yang dapat mendukung proses ini. Undang-undang yang dipakai dalam proses ini yakni Undang-undang Nomor 11 Tahun 1953. Berdasarkan Undang-undang ini maka nama De Javasche Bank diganti dengan nama Bank Indonesia. Bank Indonesia kemudian ditetapkan bukan saja sebagai bank sirkulasi, tetapi juga Bank Sentral RI.
\end{abstract}

Kata kunci: Nasionalisasi, De Javasche Bank, Bank Sentral, Bank Sirkulasi.

\section{Pendahuluan}

Sejarah Indonesia adalah sejarah dari peristiwa sederetan "kesempatan yang hilang"-diawali dari eksploitasi yang berpuluh-puluh tahun lamanya oleh imperialisme Belanda, dilanjutkan oleh upaya mobilisasi logistik perang dari tentara Pendudukan Jepang dalam Perang Dunia II, selanjutnya karena Perang Kemerdekaan yang disusul periode pergolakan politik tahun 19501966. Pembahasan sejarah dengan mengedepankan tema mengenai sejarah perbankan atau lembaga keuangan negara, merupakan tema yang cukup banyak diulas dan diteliti oleh banyak 569 | Seminar Nasional Sejarah ke 4 Jurusan Pendidikan Sejarah Universitas Negeri Padang 
penulis sejarah profesional maupun amatir. Tema mengenai sejarah perbankan dalam hal ini adalah De Javasche Bank mempunyai keunikan tersendiri dalam rumpun bahasan mengenai sejarah ekonomi di Indonesia. Uraian mengenai sejarah perbankan cukup menarik dan selalu memberikan khasanah tersendiri, hal tersebut dikarenakan mengulas sisi-sisi penting seperti regulasi, asset kenegaraan, urutan dewan direksi, kepemilikan saham serta pasang surut kondisi sosial-ekonomi-politis yang menyertai perkembangan De Javasche Bank sebelum dan setelah dinasionalisasi.

De Javasche Bank dalam sejarahnya berawal dari ketidakmampuan pemerintahan Hindia Belanda memperbaiki perekonomian dan keuangan. Hal tersebut sedikit banyak berdampak pada investor dan pengusaha swasta Belanda yang datang ke wilayah jajahan untuk mencari kesempatan yang sangat menguntungkan. Selain itu pula, rendahnya nilai mata uang Belanda, khususnya gulden Hindia Belanda, dan ketiadaan lembaga perbankan seperti yang dikenal di Eropa, membuat para pengusaha swasta Belanda tidak mampu bersaing melawan pengusaha atau pebisnis dari negara lain. Oleh karena itu, muncul gagasan dari kalangan pengusaha atau pebisnis swasta Belanda untuk mendirikan sebuah bank. Gagasan itu kemudian disampaikan kepada Mr. C.T. Elout, salah seorang anggota Komisaris Jenderal, menjelang keberangkatannya ke negeri Belanda pada tahun 1816 (Darsono, dkk., 2016: 16). Sampai tahun 1821, respon mengenai persetujuan atau penolakan gagasan itu tidak pernah sampai ke Hindia Belanda. Sementara itu, uang kartal yang dikirimkan dari negeri Belanda, terutama yang berbahan dasar emas dan perak, menghilang dari peredaran. Padahal pengiriman uang tersebut dilakukan untuk memperbaiki kondisi ekonomi Hindia Belanda (Darsono, dkk., 2016: 16).

Akhirnya, karena ketidakpastian itu mendorong John Deans, pimpinan perusahaan Deans Scoot \& Co., mengusulkan pembentukan bank kepada pemerintah kolonial pada tahun 1821. Pada intinya ia meminta agar di Hindia Belanda didirikan bank escompto dan perdagangan yang dapat membantu pebisnis Belanda sekaligus menjadi salah satu solusi masalah keuangan yang dihadapi pemerintah. Gubernur Jenderal dapat menerima usul tersebut yag kemudian diteruskan kepada Raja Willem di Den Haag. Raja menyambut usul itu dengan sangat baik dan menerbitkan oktroi untuk membentuk De Nederlandsche Oost-Indische Bank. RaJa Willem berharap pendirian bank itu dapat membantu para pedagang di Hindia Belanda (Darsono, dkk., 2016: 17).

Pada 9 Desember 1826, Raja Willem I menerbitkan Surat Kuasa kepada Gubernur Jenderal Hindia Belanda untuk membentuk suatu bank. Direktur Daerah Jajahan, J.C. Baud, Direktur 570 | Seminar Nasional Sejarah ke 4 Jurusan Pendidikan Sejarah Universitas Negeri Padang 
untuk Urusan Hindia Belanda, G. Schimnelpennick, dan dari unsur Nederlandsche Handel Mashappij (NHM) ditugasi menyusun OctrooiReglement tentang pembentukan sebuah bank yang kemudian diberi nama De Javasche Bank (DJB) (Darsono, dkk., 2016: 18). Pada 11 Desember 1827, Gubernur Jenderal L. Burggraaf Du Bus de Gisignies menerbitkan Surat Keputusan No. 28 tentang Octrooi en Reglement voor De Javasche Bank. Dalam Pasal 1 ditegaskan bahwa oktroi berlaku sejak 1 Januari 1828 sampai dengan 31 Desember 1837. Dengan demikian, sejak 1 Januari 1828 DJB berdiri. Saham bank ini dimiliki oleh perorangan, lembaga, dan dan pemerintah Kolonial. NHM merupakan pemilik saham bank terbesar (Darsono, dkk., 2016: 19).

Pada perkembangan selanjutnya, setelah Indonesia merdeka dan tampuk pemerintahan dipegang oleh bangsa Indonesia, banyak perubahan yang terjadi salah satunya dalam hal perbankan Indonesia. Berdasarkan surat kabar Suara Rakjat Republik Indonesia tanggal 6 Agustus 1951 disebutkan bahwa Menteri Keuangan Republik Indonesia, Mr. Jusuf Wibisono, menyatakan bahwa pemerintah bermaksud menasionalisasikan bank peredaran De Javasche Bank sebelum akhir tahun 1951. DJB yang sudah dinasionalisasikan ini akan menjadi bank peredaran dari Republik Indonesia dengan nama Bank Indonesia.

Nasionalisasi terhadap DJB yang dilakukan oleh pemerintah Indonesia dirasa sangat perlu karena selama awal tahun 1950-an terjadi perdebatan politik perihal langkah-langkah untuk menghilangkan kepentingan Belanda, sehingga dapat dibangun sebuah ekonomi nasional Indonesia. Sebagian aparat pemerintah mengusulkan pembongkaran kepentingan ekonomi Belanda tersebut dilakukan secara bertahap untuk mencegah gangguan ekonomi yang lebih serius. Sedangkan sebagian besar pemimpin nasional mengusulkan langkah yang lebih cepat tanpa menghiraukan ongkos jangka pendek dislokasi ekonomi dan untuk pengantian unit usaha negara maupun koperasi (Agusta, 2014: 147).

Untuk kepentingan nasionalisasi DJB itu dengan Keputusan Pemerintah No. 118 tanggal 2 Juli 1951dibentuk Panitia Nasionalisasi De Javasche Bank. Panitia tersebut mempunyai kekuasaan untuk mengambil tindakan-tindakan persiapan dan mengadakan perundingan-perundingan mengenai nasionalisasi DJB atas nama pemerintah (De Javasche Bank Laporan Tahun Pembukuan 1951-1952).

\section{Metodologi}

571 | Seminar Nasional Sejarah ke 4 Jurusan Pendidikan Sejarah Universitas Negeri Padang 
Terdapat tiga hal yang berkaitan dengan pembangunan perekonomian Indonesia yang dihadapi bangsa Indonesia, yaitu hal:

1. Ideologi : Bagaimana mengadakan susunan ekonomi yan sesuai dengan cita-cita tolong -menolong

2.Praktek: Politik perekonomian apakah yang praktis dan perlu dijalankan dengan segera di masa yang akan datang

3.Koordinasi: Bagaimanakah mengatur pembangunan perekonomian Indonesia supaya pembangunan itu sejalan dan berkelanjutan dengan pembangunan di seluruh dunia (Swasono, 1991: 4).

Pembangunan ekonomi Indonesia setelah merdeka dan diakui kedaulatannya berdasarkan atas pemikiran nasionalisme ekonomi Indonesia yang dikelola sendiri oleh bangsa Indonesia. Rumusan nasionalisme ekonomi untuk Indonesia menginginkan secara mutlak adanya suatu perubahan struktur ekonomi Indonesia. Nasionalisme ekonomi merupakan paham bersama untuk mengubah ekonomi Indonesia dari ekonomi kolonial menjadi ekonomi nasional. Paham nasionalisme ekonomi yang disepakati ini mengandung tiga komponen pokok, yaitu:

1. Diversifikasi produksi untuk menghilangkan ketergantungan atasekspor bahan-bahan mentah primer.

2. Perkembangan ekonomi dan kemakmuran yang merata.

3. Pengalihan dominasi penguasaan usaha-usaha ekonomi dari tangan asing dan golongan Cina ke tangan pribumi Indonesia (Sritua, 2006: 94).

Dalam menunjang kegiatan penelitian ini telah dilakukan studi kepustakaan anatra lain pada Perpustakaan Universitas Indraprasta PGRI, di J1. Nangka, Perpustakaan Universitas Indonesia, Depok-Jawa Barat, Perpustakaan Nasional Republik Indonesia, Jakarta.Penulisan penelitian ini menggunakan metode sejarah dengan melakukan tahapan heuristik, kritik, interpretasi, dan historiografi (Gottschalk, 1985:57) melalui riset kepustakaan (Library Research).

\section{Pembahasan}

\section{Selayang Pandang De Javasche Bank}

Berdasarkan Surat Keputusan Komisaris Jenderal No. 28 tertanggal 11 Desember 1827 ditetapkan oktroi khusus bagi De Javasche Bank sebagai ketentuan dan pedoman dalam 
menjalankan usahanya. Oktroi pertama berlaku selama 10 tahun sejak 1 Januari 1828 sampai 31 Desember 1837 dan kemudian diperpanjang sampai 31 Maret 1838. Sesuai dengan ketentuan Oktroi Pertama, modal dasar De Javasche Bank ditetapan sebesar 4 juta gulden terbagi dalam 8000 lembar saham, masing-masing memiliki nilai 500 gulden. Nilai itu harus dipenuhi dalam bentuk emas dan perak. Tahap pertama pembayaran modal disyaratkan sebesar 50\% telah mencapai $25 \%$, yaitu 1 juta gulden, yang berarti bank dapat dinyatakan berdiri dan memulai usahanya. Oleh sebab itulah, pemerintah segera menawarkan saham bank ke pasaran, terutama kepada para pengusahan atau pejabat pemerintah. Meskipun awalnya tidak berjalan dengan lancar, pada 16 Januari 1828 pihak bank telah melaporkan kepada pemerintah bahwa telah terjual 2.019 lembar saham atau setara dengan 1.009.500 gulden yang berarti telah mencapai 25 persen dari modal keseluruhan. Diantara pemilik saham De Javasche Bank itu, antara lain adalah Pemerintah Hindia Belanda telah membeli 1000 saham, Nederlandsche Handel Maattschappij (NHM) membeli 300 saham, serta beberapa pejabat pemerintah, termasuk Komisaris Jenderal Du Bus de Gisignies, juga turut membeli antara 10 dan 50 lembar saham (Kusuma, 2014:13-14).

Dengan terlewatinya angka penjualan saham yang bernilai lebih dari $25 \%$ tersebut, berarti De Javasche Bank dapat dinyatakan dibuka dan beroperasi sebagai bank sirkulasi. Berdasarkan kenyataan itu, Komisaris Jenderal du Bus mengeluarkan Surat Keputusan No. 25 tertanggal 24 Januari 1828 yang menyatakan bahwa De Javasche Bank secara resmi telah berdiri. Surat keputusan itu merupakan akta pendirian De Javasche Bank. Maka, pada 24 Januari 1828 adalah tanggal berdirinya De Javasche Bank, walaupun bank baru beroperasi pada tanggal 8 April 1828 (Kusuma, 2014:15).

Komisaris Jendera du Bus menetapkan dua orang yaitu Mr. C. De Haan yang merupakan Ketua Kantor Pengadilan Negeri Semarang, sebagai Presiden De Javasche Bank dan J.C. Smulders yang sebelumnya adalah Kepala Bea Cukai di Surabaya, sebagai Sekretaris. Kedua nama pimpinan bank ini tercantum dalam Akta Pendirian De Javasche Bank. Selanjutnya terpilih tiga direktur dari kalangan pengusaha di Batavia. Mereka adalah O.M. Roberts, Firma Thompson, Robert \& Co, C. Ten Brink, Firma Ten Brink \& Reynst, dan A.J.L Ram, Presiden Direktur Factorij der Nederlandsche Handel Maatschappij. Kendala yang harus dihadapi dalam pengangkatan direktur-direktur, yakni mengingat gaji yang mereka terima hanya 18.000 gulden setahun, lebih rendah bila dibandingkan dengan penghasilan mereka sebagai pimpinan 
perusahaan dagang. Presiden De Javasche Bank adalah pemimpin De Javasche Bank. Jabatan ini merupakan cikal bakal Gubernur Bank Indonesia, seiring dengan nasionalisasi dari De Javasche Bank ke Bank Indonesia.

\section{Nasionalisasi De Javasche Bank Menjadi Bank Indonesia}

\section{Situasi Indonesia Menjelang Nasionalisasi De Javasche Bank}

Di awal kemerdekaan Indonesia, Indonesia menghadapi tugas-tugas yang berupa menyempurakan pemerintahan sipil, membangun suatu tentara, menyempurnakan kepolisian, guna keamanan umum dan memelihara apa yang masih ada dari alat-alat perhubungan. Indonesia harus menghadapi tuntutan-tuntutan dan syarat-syarat suatu alat pemerintahan yang harus berjalan lancar. Dalam keadaan yang seperti itu, Indonesia harus menghadapi ulah Belanda yang mengadakan blokade keras terhadap Indonesia dari awal permulaan dan selama tahun-tahun beriutnya. Selain itu, Indonesia juga harus memecahkan soal-soal anggaran belanja dan keuangan (Djojohadikusumo, 1953: 20).

Setelah Jepang menyerah dalam bulan Agustus 1945, Tentara pendudukan militer telah mengedarkan kira-kira 1.500 juta rupiah Jepang. Dalam bulan-bulan berikutnya, ketika pembesar-pembesar Belanda datang kembali dan mencoba menegakkan kembali pemerintah kolonial mereka, pemerintahnya mendapatkan persediaan rupiah Jepang yang besar. Pada saat itu, rupiah Jepang merupakan alat penukaran. Tentara-tentara Belanda melemparkan persediaan rupiah Jepang ini ke dalam peredaran. Mereka menambahkan kira-kira 2.500 juta rupiah Jepang ke dalam jumlah 1500 juta tersebut setelah Jepang menyerah.

Indonesia harus menghadapi masalah bahwa di Pulau Jawa dan Madura telah beredar tidak kurang dari 4000 juta rupiah Jepang. Jika angka ini dibandingkan dengan jumlah edaran sebelum perang yang sebesar 400 juta rupiah untuk seluruh Indonesia, maka jelas bahwa adanya tambahan peredaran uang yang sangat besar ini, mengakibatkan banyak sekali inflasi merajalela di Indonesia. Keadaan lain yang memperburuk situasi perekonomian Indonesia adalah keuangan Pemerintah Indonesia yang baru didirikan itu hanya mempunyai persediaan uang yang terbatas jumlahnya guna membiayai kebutuhan-kebutuhan negara Indonesia. Uang beredar di dalam masyarakat terutama di antara para petani dan pedagang. Sebaliknya tidak ada pemasukan uang yang mengakibatkan uang tidak cukup untuk dipakai dalam menjalankan pekerjaan-pekerjaan negara (Djojohadikusumo, 1953: 21). 
Dalam hal perbankan, sistem perusahaan Bank Republik terdiri dari lima bank. Bank Negara Indonesia mengepalai bank-bank milik negara Indonesia. Bank ini memiliki tugas sebagai bank untuk para pengusaha bank. Pemerintah yang memiliki bank negara ini, dan bekerja bersama-sama dengan menteri keuangan. Di bawah bank pusat ini terdapat bank perniagaan. Pemerintah memiliki dua bank perniagaan ini dan dua lainnya adalah milik partikelir. Satu dari bank-bank pemerintah itu khusus beroperasi dalam lapangan pinjaman skala kecil untuk pertanian dan perikanan, tetapi juga memberi pinjaman kepada orang-orang pribadi. Dalam triwulan pertama dari tahun 1947, bank ini (yang dinamakan Bank Rakyat) meminjamkan hingga jumlah kira-kira 33 juta rupiah guna kepentingan pertanian dan perikanan (Djojohadikusumo, 1953: 24).

Inflasi di Indonesia merajalela sebagai akibat rangkaian keadaan-keadaan ini serta juga karena banyaknya kekurangan pemerintahan yang merupakan warisan dari pemerintahan jajahan. Peredaran uang bertambah banyak dan harga-harga di dalam negeri melambung. Pemerintah Indonesia harus mengambil langkah-langkah yang pasti untuk mengatasi masalah keuangan negara. Tindakan perdana dari pemerintah adalah mengadakan nilai mata uang asing, yang bisa dirubah-rubah.

Indonesia setelah mendapat kedaulatan secara penuh pada tahun 1949 juga menghadapi masalah perekonomian yang sangat mendesak untuk segera diatasi. Secara garis besar masalah pokok itu antara lain: pertama, tugas untuk memperbaiki perekonomian nasional yang telah mengalami kehancuran setelah pendudukan Jepang dan perang kemerdekaan; kedua, tuntutan masyarakat luas untuk mengubah ekonomi kolonial menjadi ekonomi nasional.

Sampai tahun 1950-an terdapat lima besar perusahaan Belanda di Indonesia yang ternama dengan sebutan The Big Five, yaitu Jacobson \& van den Berg, Internatio Borneo-Sumatra Maatschappij (Borsumij), Lindeteves, dan GonWehry. Banyaknya perusahaan besar Belanda tersebut memperlihatkan tidak adanya perubahan penting yang terjadi dalam struktur perekonomian Indonesia padahal kemerdekaan politik telah dicapai secara penuh.

Menghadapi keadaan perekonomian negara semacam itu, muncul berbagai pemikiran ekonomi dari para tokoh pemimpin Indonesia. Muncul pemikiran yang dikenal dengan "ekonomi nasional" atau "nasionalisasi ekonomi". Aspirasi mengenai ekonomi nasional tersusun secara garis besar mencakup tiga aspek utama, yakni: pertama, suatu perekonomian yang beragam dan stabil, dalam arti ditiadakannya ketergantungan yang besar terhadap ekspor bahan mentah. 
Kedua, pembangunan ekonomi maju dan membawa kemakmuran. Ketiga, suatu perekonomian yang dikelola pribumi, yang berarti dominasi ekonomi Barat dan etnis Cina harus dipindahkan kepada orang-orang Indonesia.

Dari pemikiran tersebut muncul desakan kuat yang menuntut nasionalisasi terhadap persahaan-perusahaan asing. Namun, pemerintah memiliki alasan bahwa tindakan nasionalisasi hanya akan membawa kerugian karena kurangnya tenaga professional Indonesia dan dikhawatirkan aksi semacam itu hanya akan mempersulit masuknya modal asing (Kanumoyoso, 2001: 9).

Masalah paling berat lainnya yang harus dihadapi oleh pemerintahan Indonesia sepanjang kurun tahun 1950-an adalah kelemahan di bidang administrasi negara. Sejak periode revolusi kemerdekaan berakhir pada akhir tahun 1949, pemerintah Indonesia yang berdaulat mulai menjalankan suatu kewajiban untuk meningkatkan kesejahteraan rakyat. Berbagai upaya perbaikan untuk mencapai tujuan kesejahteraan rakyat yang segera harus dilaksanakan pastinya memerlukan peraturan pemerintah, perencanaan dan pengawasan yang seksama, serta lembaga pelayaan umum yang cakap dan memiliki sarana yang memadai.

Masa pemerintahan Indonesia di awal tahun 1950-an memperlihatkan adanya kesenjangan antara harapan dengan realita yang dihadapi. Cita-cita untuk mewujudkan kedaulatan ekonomi sebagai hasil dari kedaulatan politik yang telah dicapai, belum dapat diwujudkan dengan segera. Tingkat kesejahteraan penduduk semakin menurun tajam. Pada tahun 1951, pendapatan perkapita orang Indonesia sebanyak 28,3 gulden, yang berarti lebih rendah dari pendapatan perkapita pada masa malaise Hindia Belanda (1930), yaitu sebesar 30 gulden (Kanumoyoso, 2001: 9).

Ketidakberhasilan dalam usaha untuk mewujudkan ekonomi nasional dengan segera ditafsirkan oleh beberapa pemimpin Indonesia sebagai kegagalan mengatasi dominasi perusahaan-perusahaan Belanda. Konferensi Meja Bundar yang ditandatangani para pemimpin Republik di Den Haag pada tahun 1949 mencakup jaminan bahwa hak-hak yang diberikan kepada modal asing akan dihormati. Hal tersebut memperlihatkan bahwa perusahaan-perusahaan Belanda tetap mengendalikan sektor-sektor ekonomi yang menguasai kepentingan bangsa Indonesia (Kanumoyoso, 2001: 18).

Sikap pemerintah Indonesia terhadap modal asing sepanjang tahun 1950-an sangat kuat dipengaruhi pengalaman zaman kolonial Hindia Belanda. Pandangan yang berlaku terhadap 
modal asing, khususnya modal Belanda, secara umum melihat kehadiran mereka menjadi penghambat bagi terwujudnya kedaulatan di bidang ekonomi. Hal itu tidak terlepas dari peranan modal asing yang sampai saat itu dijalankan hanya untuk menarik keuntungan ekonomi sebesarbesarnya dari Indonesia, tanpa turut berpartisipasi dalam perbaikan ekonomi untuk meningkatkan taraf hidup rakyat secara umum.

Sikap tidak peduli para pemilik modal asing pada akhirnya memunculkan sikap tidak suka dari kalangan orang-orang Republik. Tidak mengherankan pula jika sikap pemerintah Indonesia terhadap modal asing menjadi tidak terlalu bersahabat. Apalagi hampir sepanjang kurun waktu 1950-an sektor-sektor modern ekonomi Indonesia masih dikuasai perusahaanperusahaan Belanda. Dalam situasi demikian, mengemuka pendapat yang mendesak pemerintah Indonesia untuk secara bertahap mengurangi dominasi perusahaan-perusahaan Belanda dan sekaligus mendorong munculnya pengusaha-pengusaha pribumi Indonesia (Kanumoyoso, 2001: 36).

Telah diketahui bahwa tidak ada jaminan jika sektor-sektor ekonomi yang penting dikuasai modal asing, mereka akan membantu pemerintah dalam mengatasi kesulitan-kesulitan ekonomi di dalam negeri. Modal asing dinilai tidak memiliki kepentingan yang kuat terhadap kondisi ekonomi dalam negeri. Bila situasi di Indonesia menjadi tidak kondusif bagi modal asing, mereka bisa menarik modalnya setiap saat untuk menyelamatkan diri.

Sebaliknya nasionalisasi perusahaan-perusahaan tidak menjamin bahwa jalannya sektorsektor perekonomian akan menjadi rasional sehingga harga barang dapat ditekan serendahrendahnya dan spekulasi ditiadakan. Namun dengan didasari oleh pertimbangan bahwa kedaulatan ekonomi Indonesia sulit untuk ditegakkan tanpa melakukan nasionalisasi, maka langkah nasionalisasi mendapat dukungan luas meskipun pemerintah tetap berusaha bertindak rasional. Selaras dengan konsolidasi politik pasca penyerahan kedaulatan yang menitkberatkan unsur-unsur nasional, di bidang ekonomi diusahakan untuk merombak struktur perekonomian yang sampai saat itu masih bercorak kolonial. Struktur ekonomi kolonial dengan sendirinya tidak mendukung sifat berdaulat dari negara Indonesia yang telah merdeka. Sedangkan tujuan dari kemerdekaan adalah mewujudkan masyarakat yang adi dan makmur. Untuk mencapai masyarakat yang demikian maka perombakan ekonomi kolonial menjadi ekonomi nasional menjadi keharusan (Kanumoyoso, 2001: 42). 
Langkah-langkah pemerintah Indonesia dalam rangka merombak ekonomi kolonial itu satu diantaranya adalah pada tahun 1951 pemerintah telah mendirikan NV Bank Industri Negara (BIN). Sebenarnya nama bank kurang tepat diberikan kepada BIN. Dalam kegiatannya bank ini tidak melakukan transaksi keuangan, tidak menerima uang simpanan dari masyarakat, tidak menyediakan rekening Koran serta tidak member jasa perantara. Tugas utama dari BIN adalah memberi kredit jangka panjang kepada usaha-usaha industri yang berada di bawah program Rencana Urgensi Perekonomian.

Sejak awal tahun 1950-an terjadi perdebatan politik perihal langkah-langkah untuk menghilangkan kepentingan Belanda, sehingga dapat dibangun sebuah ekonomi nasional Indonesia. Sebagian aparat pemerintah mengusulkan pembongkaran kepentingan ekonomi Belanda tersebut dilakukan secara bertahap untuk mencegah gangguan ekonomi yang lebih serius. Sedangkan sebagian besar pemimpin nasional mengusulkan langkah yang lebih cepat tanpa menghiraukan ongkos jangka pendek dislokasi ekonomi dan untuk penggantian unit usaha negara maupun koperasi.

Untuk mengembangkan kewirausahaan pribumi Indonesia dan meletakkan kegiatan ekonomi yang penting di bawah kontrol nasional, pada tahun 1950 pemerintah memperkenalkan Program Benteng yang memberikan izin-izin dan kredit impor kepada importir pribumi. Hal ini membuahkan hasil pada pertengahan tahun 1950-an. Sekitar 70\% perdagangan impor Indonesia ditangani oleh para pengusaha Indonesia. Program Benteng terfokus pada pengamanan kontrol nasional atas perdagangan impor. Sektor ini bukan hanya paling rentan terhadap kontrol negara melalui alokasi izin impor tetapi juga hampir dapat dimasuki oleh para calon pengusaha Indonesia. Hal ini karena jumalah modal dan sumber-sumber daya perusahaan yang diperlukan relatif kecil dibandingkan kegiatan-kegiatan lain seperti manufaktur. Diharapkan bahwa melalui perdagangan impor ini para pengusaha pribumi Indonesia lambat laun akan mampu mengakumulasi modal yang cukup untuk masuk ke sektor-sektor lain (Agusta, 201: 147).

\section{Proses De Javasche Bank Menjadi Bank Indonesia}

Konferensi Meja Bundar (KMB) diselenggarakan di Den Haag, Belanda pada 23 Agustus sampai 2 November 1949. Selain menghasilkan kesepakatan berdirinya negara Republik Indonesia Serikat (RIS), KMB juga menghasilkan Persetujuan Keuangan dan Perekonomian. Dalam KMB inilah disepakati pula bahwa yang ditunjuk sebagai bank sirkulasi untuk RIS adalah De Javasche Bank (DJB), sedangkan Bank Negara Indonesia (BNI) ditugaskan sebagai bank 
pembangunan (Kusuma, 2014: 89). Dalam forum KMB, Sumitro Djojohadikusumo yang menjadi anggota delegasi Indonesia menyatakan penolakannya atas penunjukkan DJB sebagai bank sirkulasi. Menurut Sumitro, seharusnya BNI lah yang berhak menjadi bank sentral atau sirkulasi untuk RIS karena bank negara itu dibentuk pada 1946 untuk keperluan itu. Terkait hal itu, Sumitro menyatakan kekecewaannya dengan mengatakan:

“... Mengenai peran bank sentral, saya menginginkan agar BNI menjadi bank sentral, itu adalah bank kita sendiri. Seperti Simatupang menginginkan tentara republiklah yang menjadi TNI, jadi bukan KNIL, begitulah saya menginginkan BNI menjadi bank sentral. Simatupang berhasil, sedangkan saya tidak!” Betapapun primitifnya TNI, ia adalah tentara kita! Sama ;juga dengan BNI, saya merasa itu adalah bank kita (Kusuma, 2014: 92-93).

Pada dasarnya DJB merupakan lembaga milik swasta Belanda pertama yag dinasionalisasi oleh Pemerintah RIS. Tak lama setelah ditetapkan menjadi bank sirkulasi bagi RIS, maka sejak awal tahun 1950 Pemerintah RI mulai memasukkan personel baru ke dalam jajaran kepegawaian bank tersebut (Darsono.,dkk, 2016: 234).

Dalam situasi maraknya wacana nasionalisasi perusahaan-perusahaan milik Belanda, ternyata masih banyak pula kaum nasionalis Indonesia yang berpikir secara lebih jernih dalam memutuskan perlu atau tidaknya melakukan nasioanalisasi terhadap DJB atau lembaga-lembaga lainnya milik swasta Belanda. Menurut kelompok ini, dalam melakukan nasionalisasi perusahaan-perusahaan asing itu perlu mempertimbangkan baik buruknya bagi perkembangan ekonomi Indonesia dan khususnya ekonomi rakyat Indonesia yang baru saja mengalami masa peperangan. Rencana untuk menasionalisasi DJB diwujudkan dengan pertama-tama membentuk Panitia Nasionalisasi DJB yang disahkan keberadaannya pada 2 Juli 1951. Panitia inilah yang kemudian melakukan berbagai persiapan, termasuk menjaring berbagai pendapat tentang baik buruknya pengambilalihan kepemilikan lembaga perbankan tersebut. Bank sirkulasi dan bank sentral mempunyai makna sebagai kedaulatan bangsa sehingga akhirnya panitia memutuskan untuk melakukan pengambilalihan kepemilikan ini dengan cara indonesianisasi sahamsahamnya. Atas dasar keputusan itulah maka pada 3 Agustus 1951, pemerintah RI secara resmi mengajukan penawaran untuk membeli saham-saham bank tersebut kepada pemiliknya.

Selanjutnya, diplomasi oleh delegasi Indonesia berhasil meyakinkan Vereeniging voor de Effectenhandel (Perkumpulan Pedagang Efek), Amsterdam, bahwa Pemerintah Republik 
Indonesia akan membayar saham-saham itu secara wajar. Ternyata banyak pemilik saham yang tertarik dengan penawaran itu, sehingga pemerintah RI berhasil menguasai sekitar $97 \%$ saham bank tersebut dengan harga pembelian $20 \%$ di atas normal.

Landasan hukum tetap diperlukan, karena itu pada Desember 1951 pemerintah RI mengumumkan tentang Undang-undang Nasionalisasi DJB, yang dimuat dalam Lembaran Negara RI No. 120 Tahun 1951. Proses Indonesianisasi DJB semakin jelas dan semakin mengerucut ketika pada September 1952, pemerintah RI mengajukan ke Parlemen (Konstituante) satu Rancangan Undang-undang Pokok Bank Indonesia. Pada tanggal 10 April 1953, parlemen menyatakan setuju terhadap rancangan yang diajukan pemerintah. Atas persetujuan parlemen, pada 29 Mei 1953 Presiden RI mengesahkan rancangan itu menjadi Undang-undang Nomor 11 Tahun 1953 tentang Bank Indonesia, yang kemudian diundangkan melalui Lembaran Negara No. 40 Tahun 1953. Undang-undang itu mulai berlaku sejak 1 Juli 1953. Dengan berlakunya Undang-undang Nomor 11 Tahun 1953, maka nama DJB diganti dengan nama Bank Indonesia. Bank Indonesia kemudian ditetapkan bukan saja sebagai bank sirkulasi, tetapi juga Bank Sentral RI.

Sejak berlakunya UU No. 11 Tahun 1953, maka nama Bank Indonesia secara resmi digunakan sebagai Bank Sentral NKRI. Penggunaan nama ini sesuai dengan bunyi Pasal 1. Selain itu dalam Pasal 3 disebutkan pula bahwa kedudukan Bank Sentral adalah di Jakarta, serta mempunyai kantor-kantor agen, kantor-kantor koresponden, dan kantor-kantor perwakilan baik di dalam maupun luar negeri. Selanjutnya Pasal 4 disebutkan bahwa modal bank adalah Rp. 5.000.000 (Darsono.,dkk, 2016: 244).

Berdasarkan UU No. 11 Tahun 1953, struktur pucuk pimpinan BI mengalami perubahan. Pimpinan BI terdiri dari tiga dewan, yaitu Dewan Moneter, Dewan Direksi, dan Dewan Penasihat. Susunan Dewan Direksi yang menjadi penanggung jawab terseenggaranya fungsifungsi Bank Sentral, terdiri dari Gubernur dan sekurang-kurannya duaorang Direktur. Jumlah direktur ini dapat ditambah sebanyak-banyaknya empat orang. Semua anggota Dewan Direksi harus berkewarganegaraan Indonesia, dan diangkat oleh pemerintah atas usul Dewan Moneter. Gubernur Pertama BI adalah Mr. Sjafruddin Prawiranegara yang sebelumnya menjabat sebagai Presiden Direktur DJB. Sebagai Direktur merangkap Gubernur Pengganti II adalah Mr. Indra Koesoema. Sementara Dewan Penasihat terdiri dari 9 orang anggota yang mewakili dunia perusahaan, perburuhan dan pertanian serta golongan lain dari kalangan masyarakat. 
Berdasarkan Keputusan Presiden Republik Indonesia No. 194, 19, 14 November 1953, telah diangkat Rh. Koesan sebagai ketua Dewan Penasihat dengan anggotanya terdiri dari A.A. Achsien, Ir. Sostrohadikoesoemo, M.I. Dauley, S. Goendo Koesoemo, Jusuf Wibisono, Ir. Tedjasukmana, O. Rondonuwu, dan Soele.

Jumlah pegawai BI pada paruh awal dekade1950-an tercatat sebanyak 1.338 orang, 787 orang diantaranya adalah pegawai kantor pusat. Tenaga ahli, terutama untuk mengisi eselon atas dan tingkat pejabat masih sangat kurang. Dari 8 jabatan Direktur Muda, tidak satupun dijabat oleh orang Indonesia. Demikian pula beberapa jabatan yang memerlukan keahlian, seperti pengawas bank yang sangat penting bagi BI sebagai Bank Sentral, sebagian besar masih dijabat oleh warga negara Belanda (Darsono.,dkk, 2016: 247).

Sjafruddin Prawiranegara memerintahkan dalam rangka memperbaiki kondisi lembaga tersebut, sekaligus melakukan Indonesianisasi kepegawaian, maka BI menyelenggarakan pelatihan dan praktek kerja bagi calon staf di Kantor Pusat selama 6 tahun dan di luar negeri selama 6 tahun.

\section{Simpulan}

Komisaris Jenderal du Bus mengeluarkan Surat Keputusan No. 25 tertanggal 24 Januari 1828 yang menyatakan bahwa De Javasche Bank secara resmi telah berdiri. Para pemilik saham De Javasche Bank, antara lain adalah Pemerintah Hindia Belanda, Nederlandsche Handel Maattschappij (NHM), serta beberapa pejabat pemerintah termasuk Komisaris Jenderal Du Bus de Gisignies. Komisaris Jendera du Bus menetapkan dua orang yaitu Mr. C. De Haan sebagai Presiden De Javasche Bank dan J.C. Smulders sebagai Sekretaris De Javasche Bank.

Rencana untuk menasionalisasi DJB diawali dengan membentuk Panitia Nasionalisasi DJB yang disahkan keberadaannya pada 2 Juli 1951. Pada 3 Agustus 1951, pemerintah RI secara resmi mengajukan penawaran untuk membeli saham-saham bank tersebut kepada pemiliknya. Presiden RI mengesahkan rancangan itu menjadi Undang-undang Nomor 11 Tahun 1953 tentang Bank Indonesia, yang kemudian diundangkan melalui Lembaran Negara No. 40 Tahun 1953. Undang-undang itu mulai berlaku sejak 1 Juli 1953. Dengan berlakunya Undang-undang Nomor 11 Tahun 1953, maka nama DJB diganti dengan nama Bank Indonesia. Undang-Undang Pokok Bank Indonesia menetapkan pendirian Bank Indonesia untuk menggantikan fungsi De Javasche Bank sebagai bank sentral, dengan tiga tugas utama di bidang moneter, perbankan, dan sistem 
pembayaran. Di samping itu, Bank Indonesia diberi tugas penting lain dalam hubungannya dengan Pemerintah dan melanjutkan fungsi bank komersial yang dilakukan oleh DJB sebelumnya. Bank Indonesia kemudian ditetapkan bukan saja sebagai bank sirkulasi, tetapi juga Bank Sentral RI. Sejak berlakunya UU No. 11 Tahun 1953 itu pula maka nama Bank Indonesia secara resmi digunakan sebagai Bank Sentral NKRI.

Bangsa Indonesia patut berbangga karena dengan kemampuan yang dimiliki bangsa ini telah berhasil menasionalisasi DJB yang kemudian menjadikannya sebagai Bank Sentral dan Bank Sirkulasi yang dikelola oleh bangsa Indonesia sendiri. Dengan mempelajari sejarah perjalanan bangsa Indonesia khususnya mengenai sejarah DJB, sudah menjadi keharusan bagi bangsa Indonesia untuk mengelola DJB yang kini telah menjadi Bank Indonesia untuk kesejahteraan masyarakat Indonesia.

\section{DAFTAR PUSTAKA}

Agusta, Ivanovich. 2014. Ketimpangan Wilayah dan Kebijakan Penanggulangan di Indonesia: Kajian Isu Strategis, Historis, dan Paradgmatis Sejak Pra Kolonial. Jakarta: Pustaka Obor Indonesia.

Djojohadikusumo, Sumitro. 1953. Persoalan Ekonomi di Indonesia. Djakarta: Indira.

De Javasche Bank. 1952. Laporan Tahun Pembukuan 1951-1952. Djakarta: G. Kolit \& Co.

Kanumoyoso, Bondan. 2001. Menguatnya Peran Ekonomi Negara: Nasionalisasi Perusahaanperusahaan Belanda di Indonesia 1957-1959. Jakarta: Sinar Harapan

Gottschalk, Louis. 1985. Mengerti Sejarah. Depok: UI Press.

Kusuma, Erwien. 2014. Dari De Javasche Bank Menjadi Bank Indonesia. Jakarta: P.T. Kompas Media Nusantara.

Suara Rakjat Republik Indonesia 6 Agustus 1951.

Sritua, Arief. 2006. Negeri Terjajah: Menyikap Ilusi Kemerdekaan. Yogyakarta: Resist Book. Swasono , Edi Sri (ed). 1991. Sistem Ekonomi dan Demokrasi Ekonomi. Depok: UI Press 